\title{
Voces Ceibes: oralidad, paisaje y memoria en la Ribeira Sacra (Galicia, España)
}

\author{
Voces Ceibes: orality, landscape and memory in the Ribeira \\ Sacra (Galicia, Spain)
}

\author{
Enviado em: 30/09/2020 \\ Aceito em: 05/01/2021 \\ Xurxo Ayán ${ }^{1}$ \\ Olga Novo ${ }^{2}$ \\ Xosé Gago ${ }^{3}$
}

\section{Resumen}

El gobierno autonómico de Galicia (España) está intentando que una región vinícola del interior del país sea declarada Patrimonio de la Humanidad por la UNESCO. Desde finales del siglo XIX una élite intelectual ha fraguado un relato hegemónico sobre el origen y evolución de este espacio, bautizado como Ribeira Sacra por el número de eremitorios y monasterios medievales que allí se concentran. La construcción de este paisaje imaginario se basa en mitos eruditos (el vino se exportaba a Roma) y en la asunción de un marco ideológico nacionalcatólico. Hasta el momento, la ciencia y el imaginario colectivo de las comunidades locales han sido marginalizados en todo este proceso. En contraposición a esta realidad, venimos desarrollando desde finales de 2018 un proyecto interdisciplinar llamado Adegas da Memoria, centrado en el estudio integral del paisaje cultural de la parroquia de San Mamede de Vilachá (A Pobra do Brollón, Lugo). Nuestro objetivo es llevar a cabo una Arqueología Rural que parta de la tradición oral y que nos permita dar voz a una comunidad campesina subalternizada por el discurso tecnocrático oficial. Guiados por la cartografía simbólica manejada por los vecinos y vecinas de Vilachá, llevamos a cabo prospecciones, excavaciones arqueológicas, entrevistas y una serie documental disponible en la Red. Nuestro trabajo, a caballo entre la etnoarqueología, la arqueopoética y la fenomenología del paisaje, reivindica la plena validez de la memoria oral del mundo rural como fundamento empírico de un relato científico riguroso sobre la genealogía y el devenir histórico de este paisaje cultural.

Palabras Clave: Oralidad; Arqueopoesía; Memoria; Cultura gallega.

\footnotetext{
Abstract

1 - Instituto de História Contemporânea, Universidade Nova de Lisboa.

2 - Instituto de Educación Secundaria A Pinguela, Monforte de Lemos, Espanha

3 - Concello de A Pobra do Brollón, Espanha
}

The autonomous government of Galicia (Spain) is trying to have a wine region in the interior of the country declared a World Heritage Site by UNESCO. Since the end of the 19th century, an intellectual elite has forged a hegemonic story about the origin and evolution of this space, baptized as Ribeira Sacra due to the number of medieval

Revista Memória em Rede, Pelotas, v.13, n.24, Jan/Jul.2021 - ISSN- 2177-4129

periodicos.ufpel.edu.br/ojs2/index.php/Memoria 
hermitages and monasteries that are concentrated there. The construction of this imaginary landscape is based on scholarly myths (wine was exported to Rome) and on the assumption of a national Catholic ideological framework. So far, science and the collective imagination of local communities have been marginalized throughout this process. In contrast to this reality, since the end of 2018 we have been developing an interdisciplinary project called Adegas da Memoria, focused on the comprehensive study of the cultural landscape of the San Mamede de Vilachá parish (A Pobra do Brollón, Lugo). Our objective is to carry out a Rural Archeology that starts from oral tradition and that allows us to give voice to a peasant community subalternized by the official technocratic discourse. Guided by the symbolic cartography managed by the residents of Vilachá, we carry out surveys, archaeological excavations, interviews and a documentary series available on the Web. Our work, halfway between ethnoarchaeology, archaeopoetics and landscape phenomenology, claims the full validity of the oral memory of the rural world as the empirical foundation of a rigorous scientific account of the genealogy and the historical evolution of this cultural landscape.

Keywords: Orality; Archaeopoetry; Memory; Galician culture.

\section{Introducción}

Now those memories come back to haunt me They haunt me like a curse Is a dream a lie if it don't come true Or is it something worse

That sends me down to the river Though I know the river is dry That sends me down to the river tonight Down to the river My baby and I Oh down the river we ride

Bruce Springsteen. "The River".

Galicia es un Finisterre atlántico que siempre vio en el océano un mar de oportunidades. El mundo rural en esta esquina de la península ibérica se caracterizó por una notable presión demográfica, un hábitat disperso y por un régimen de propiedad minifundista. En el último tercio del siglo XIX se desarrolló el primer gran ciclo migratorio del campesinado gallego, con Argentina, Uruguay, Cuba y Estados Unidos como destinos preferentes. A ese le siguieron otros a lo largo del siglo XX hasta convertir el campo de nuestro país en un desierto demográfico, en el último foco de resiliencia de unas comunidades rurales envejecidas que se resisten a dejar de ser. Desde las administraciones solo se contempla una opción de cara al futuro: la integración de esta gente en las dinámicas del mercado y la potenciación del turismo rural. Este es el proceso histórico vivido en la zona sur de la provincia de Lugo, en la 
comarca natural conocida históricamente como Terra de Lemos, limitada al oeste por el río Miño y al sur por el río Sil. En las últimas dos décadas, el poder ha construido ideológicamente un paisaje imaginado (la Ribeira Sacra) con el que se pretende obtener de la UNESCO su declaración como Patrimonio de la Humanidad ${ }^{4}$ (AYÁN, SEÑORÁN, 2016).

El pasado 16 de febrero de 2020 moría a los 83 años Manuel Vázquez Rivera (O' Morales), vecino de la parroquia de San Mamede de Vilachá de Salvadur (ayuntamiento de A Pobra do Brollón). Las parroquias (feligresías) nacieron en Galicia en época altomedieval (siglos XI-XII). Están formadas por varias aldeas que comparten una iglesia. Son enclaves de naturaleza religiosa y base territorial que no son reconocidos legalmente por el Estado español. Sin embargo, siguen siendo el referente identitario para las comunidades rurales gallegas. Actualmente se integran en el territorio de los ayuntamientos, creados en el siglo XIX. O' Morales era uno de esos parroquianos humildes, anónimos, uno de esos campesinos que han servido de soporte para discursos identitarios (desde el regionalismo decimonónico al nacionalismo gallego, pasando por el fascismo) pero que nunca ha sido tomado en serio. ¿Pueden los subalternos hablar? se preguntaba Spivak en un texto ya clásico (SPIVAK, 1988).

4 - https://candidaturaribeirasacra.gal/ 


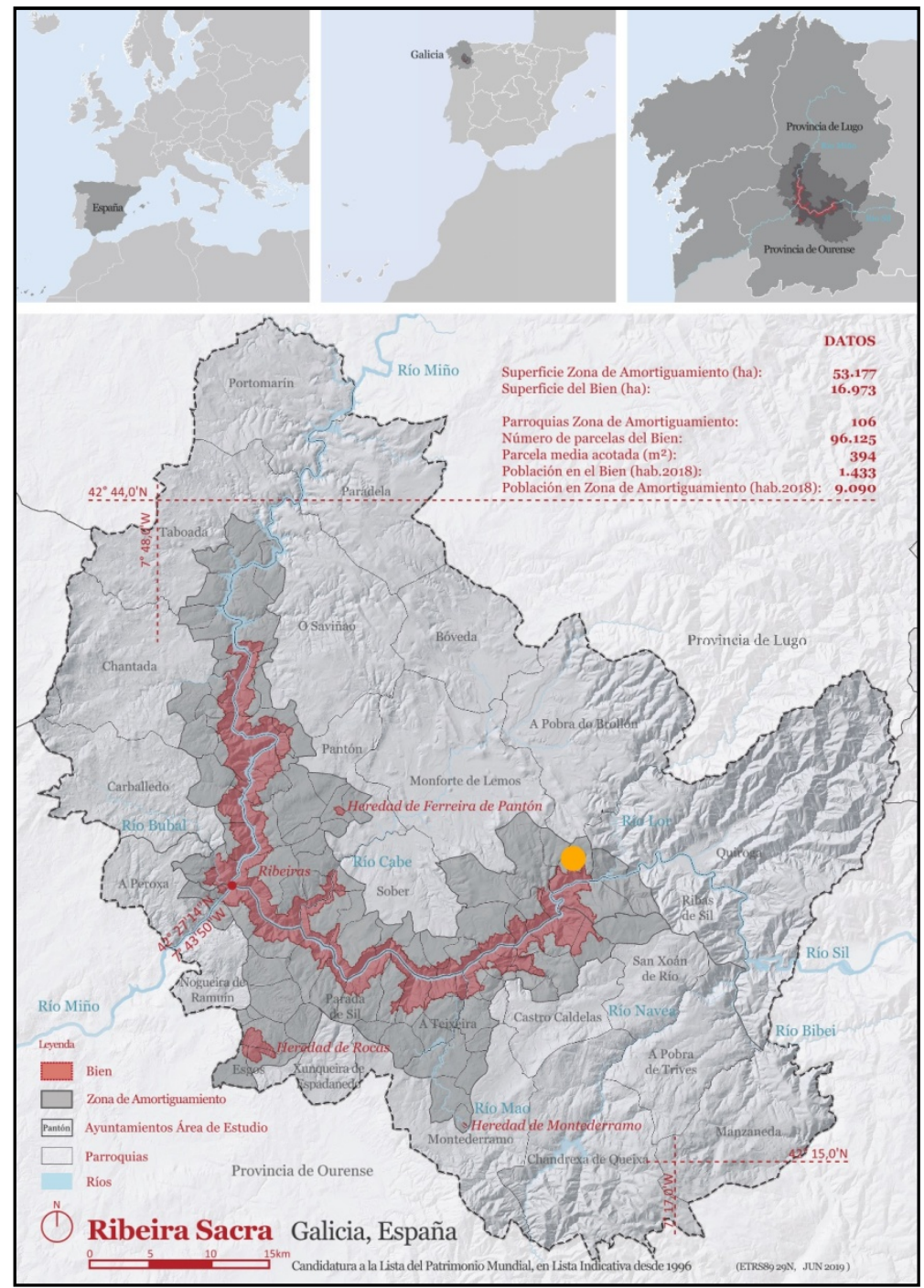

Figura 1. Ubicación de Vilachá dentro del área de la Ribeira Sacra incluida en la candidatura oficial para ser declarada Patrimonio de la Humanidad (Fuente: Xunta de Galicia).

O'Morales era un puntal del proyecto Adegas da Memoria (Bodegas de la Memoria) desarrollado por nosotros a lo largo del último año y medio en la citada parroquia de Vilachá. Durante todo este tiempo, este señor, octogenario bodeguero, nos fue decodificando el paisaje a pequeños sorbos, ejerció de anfitrión, guía e intérprete de este mundo de la Ribeira, un espacio vitivinícola espectacular, construido en las empinadas laderas del cañón del río Sil. El fallecimiento de este vecino de Vilachá ocurrió poco antes del inicio de la pandemia de la COVID-19 y aviva el sentimiento de ruina que se ha instalado entre nosotros. Es un símbolo de un mundo que está desapareciendo, en vino y en directo. Nuestro amigo formaba parte de una generación que vivió los grandes cambios de la Ribeira, desde el paisaje de su 
infancia y juventud (una Arcadia fluvial rica en pesca e intercambios socioculturales entre ambas márgenes del río), hasta la transformación perpetrada por la depredación electrofascista del franquismo a través de la construcción de grandes centrales hidroeléctricas (CHÁVARRI, 2010). Posteriormente, ya a fines de la década de 1980 vivió la creación de la Denominación de Origen Ribeira Sacra y la implantación de grandes grupos empresariales en la zona. La llegada de los fondos europeos (la Galicia rural sobrevive porque está subvencionada) aceleró los cambios tecnológicos, la mecanización de la Ribeira, la sustitución de los caminos de carro por pistas para los Citröen C15s. También conllevó la implantación de un enfoque folklorizante por parte del poder, materializado en la rehabilitación de las bodegas de Vilachá y su conversión en conjunto etnográfico. O' Morales se quedó a las puertas de convertirse él mismo en un bien cultural, en ser declarado Patrimonio de la Humanidad y de saludar desde las viñas a los turistas que navegan por el río Sil en un catamarán, cual safari acuático.

O' Morales es memoria viva de todo el siglo $\mathrm{XX}$, de esa memoria que hemos querido recuperar en el marco del proyecto Adegas da Memoria. Una iniciativa que pretende articular relatos patrimoniales contrahegemónicos, reivindicar el carácter resiliente de los últimos campesinos y las últimas campesinas de Europa y reactivar la tradición oral como herramienta de esperanza, y, por lo tanto, de un futuro que es para siempre (GODINHO, 2017).

\section{Un proyecto de Arqueología en Comunidad}

Adegas da Memoria es un proyecto que surge desde abajo, desde la propia comunidad local. La Asociación de Veciños de Vilachá decidió en asamblea en diciembre de 2018 promover y cofinanciar esta iniciativa, en colaboración con el ayuntamiento de A Pobra do Brollón. El programa de actuaciones cuenta desde entonces con la asesoría científica del Instituto de Ciencias del Patrimonio del Consejo Superior de Investigaciones Científicas y del Instituto de História Contemporânea de la Facultade de Ciencias Sociais e Humanas de la Universidade Nova de Lisboa.

La Ribeira, como buen paisaje cultural, es multidimensional, polisémica y multiversal. Aquí conviven la ciencia de los sulfatos con el mito de cantarle a las viñas, como nos recuerda Jesús Vila Regueiro O'Corenta (69 años): Yo siempre digo que el vino no me hace daño porque lo conozco desde que nace. Hablo con las cepas, les canto algo. Por ello, Adegas da Memoria es también multiversal. En el equipo conviven 
poetas con arqueólogas, edafólogas con cineastas, el presidente de la European Association of Archaeologists con O'Morales, seres míticos como O' Aláparo con santos que se escapan de noche para volver a su piedra en el cañón del Sil. En este sentido, es un proyecto que va más allá incluso de la Arqueología emocional (TARLOW, 2012; HAMILAKIS, 2017), al defender toda una arqueopoética del paisaje, basada en el verso libre de las voces ceibes ${ }^{5}$ que han sido silenciadas, las de los hombres, mujeres y niños que construyeron este paisaje.

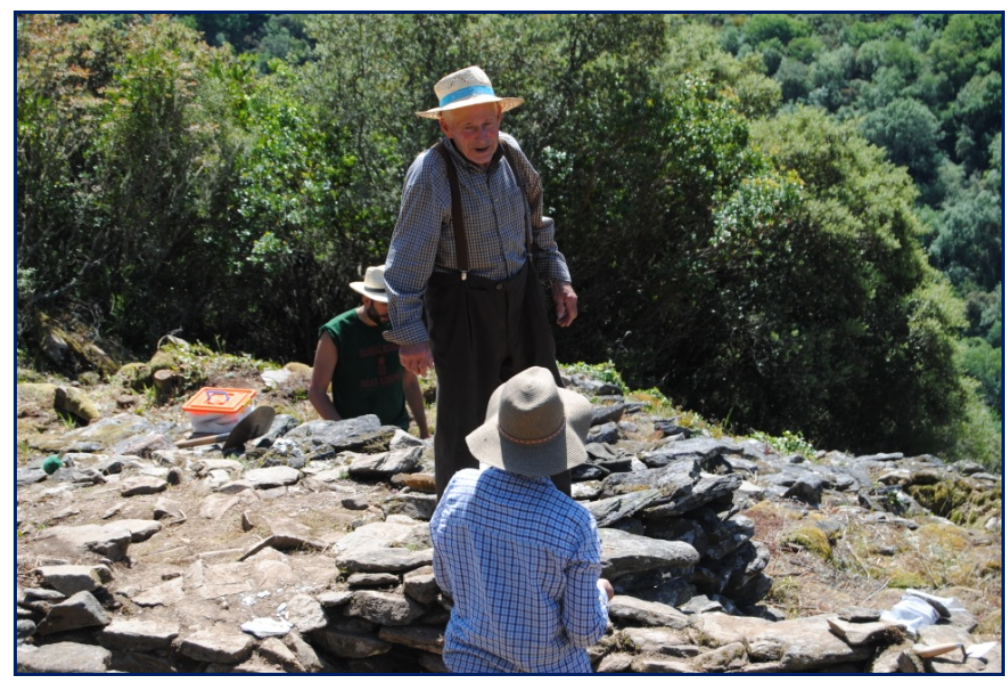

Figura 2. O' Morales en la excavación de Os Conventos, con el arqueólogo Rodrigo Paulos Bravo y la edafóloga Cruz Ferro. Mayo de 2019 (Fotografía de Ursula Neilson).

\section{Arqueopoesía (habitar con pasión el yacimiento)}

O que vemos não é o que vemos, senão o que somos.

Fernando Pessoa.

Habito con pasión el pensamiento, escribió el poeta gallego José Ángel Valente (2006: 208). Quizás desde ese fósil director podemos decir que habitamos con pasión la poesía, y que habitamos con poesía la pasión. Es decir: que habito, con pasión.

Lo verdaderamente habitable, lo sabemos al menos desde Hölderlin, es la belleza, que se identifica con la verdad. Porque la belleza es verdad y la verdad,

\footnotetext{
${ }^{5}$ Ceibe en idioma gallego significa libre. Voces Ceibes es el nombre con el que se conoce a un grupo de músicos gallegos que interpretaban canción-protesta en los estertores del régimen franquista. Este movimiento (1968-1974) surgió inspirado en la Nova Cançó catalana y se enmarcó en las revueltas estudiantiles vividas en la universidad de Santiago de Compostela en aquella época (Araguas 1991).
} 
belleza, y por ello también amamos, si seguimos a Diótima de Mantinea (PAGÉS, 2018).

Desde luego, para poder hablar desde este lenguaje no escindido de la existencia como amor habitado, parece necesario y tal vez urgente un regreso al lenguaje originario -que ha sido corrompido y ocupado por la Historia, como advierte el poeta Claudio Rodríguez Fer (2011)-. Y este regreso pasa sin duda por el retorno a la matriz de la piedra: la poesía es siempre una prospección geológica, una búsqueda de lo que no sabemos, un camino a la revelación que se encarna en la materia, en las materias, a veces tan hermosamente fragmentarias como los versos de Safo, que no por ello dicen menos sino que resaltan la emoción de lo no-dicho, de lo perdido pero de algún modo presente para siempre en el hueco en que se apoyan las palabras que han perdurado. Presente, desde luego, en la conmoción del balbuceo, del temblor, de la inminencia, de lo imperfecto, de lo roto, y del eco que reverbera en toda ruina.

Desde un sentir ultrarromántico todos somos ruinas, pero en ello convergen como en casi todo lo profundo-, la poesía y la ciencia -que acaso sean lo mismo, conocimiento al fin-: Somos depósitos cuaternarios formados por el arrastre de multitud de diferencias. Material epigenético que recuerda en el caudal de la sangre la intensidad emocional de la vida de nuestros antepasados. Somos un árbol en medio de un bosque de cromosomas, un árbol que es también el bosque porque forma parte de su heteroglosia. Un fragmentum. Regresamos entonces a Valente con un pequeño pincel de arqueólogo en la mano: "El fragmento interroga a la totalidad y esa interrogación revela la inanidad del discurso impositivo, unívoco, monosémico, totalitario en suma" (VALENTE, 1998).

La arqueología se acerca no solo al fragmento fósil enterrado en el subsuelo, sino al canto comunal de los informantes, del que, no obstante, escucha fragmentos, valiosos y bellos en sí mismos, como cuando encontramos el resto de un fémur desde el que tenemos que ver crecer en nuestra mente un cuerpo. Y con el precioso cuidado del antropólogo, debe entonces el o la arqueóloga observar la realidad como un diluvio de signos, tal y como Carmelo Lisón Tolosana describe su oficio (LISÓN, 2000). La escucha como bien sagrado se hace aquí imprescindible. El dejar hablar. El dejar paso al logos ajeno. Abrirse, en fin, a la maravilla del palimpsesto sin temer la contradicción, el camino incierto y el desbordamiento que supone el encuentro con lo imprevisto.

Desde esta perspectiva, la certeza -como datación de un resto-, solo puede hacerse con Carbono 14 y mucho amor. $Y$ tal vez, solo quien habita (con pasión) esté realmente preparado para el encuentro con el fósil que (nos) habla, porque lo 
imprevisible es siempre un sobresalto. Esa es precisamente la naturaleza de la creación -poética-: ir al encuentro de lo que no sabemos, y con impulso vital y poiésico, restaurar las ruinas y habitar el abandono.

Desde ese lugar escribimos y miramos el mundo, desde la más profunda necesidad arqueopoética que nos explica como fragmentos e ilumina nuestro propio bosque de cromosomas. Yo, Olga Novo, soy hija de labriegos de una aldea del fin del mundo, y por ello sé que la memoria restaurada exige, en mi caso, cavar como lo hace Seamus Heany cuando la azada de su padre deviene la pluma del escritor, pero sé también que la restauración de la memoria exige el excavar y el recordar de Walter Benjamin (2010: 350):

es imprescindible dar la palada a tientas hacia el oscuro reino de la Tierra, de modo que se pierde lo mejor aquel que sólo hace el inventario fiel de los hallazgos y no puede indicar en el suelo actual los lugares en donde se guarda lo antiguo. Por ello los recuerdos más veraces no tienen por qué ser informativos, sino que nos tienen que indicar el lugar en el cual los adquirió el investigador. Por tanto, stricto sensu, de manera épica y rapsódica, el recuerdo real debe suministrar al mismo tiempo una imagen de ese que recuerda, como un buen informe arqueológico no indica tan sólo aquellas capas de las que proceden los objetos hallados, sino, sobre todo, aquellas capas que antes fue preciso atravesar.

Por todo ello, así como a la poesía le interesó la ruina, de igual modo halló en la prospección arqueológica su método de busca de la identidad individual y colectiva. Pero no menos debe interesar a la arqueología la prospección emocional -de nuevo individual y colectiva-, y excavar con esa herramienta. La densidad de un proyecto se mide en muchas ocasiones por la intensidad del recuerdo.

Adegas da memoria se explica, en este sentido, como un repositorio plural sub terra -unas bodegas- de lo recordado, de aquello que todavía no ha caído definitivamente en el olvido gracias a la comunidad rural del presente y del pasado, conectadas preci(o)samente por la memoria. Y es que la bodega no solo actúa como repositorio, sino como espacio de conservación. Es en ese lugar, que actúa como substrato comunal, donde se lleva a cabo la protección de los bienes necesarios: la tradición oral que lleva, en su propia naturaleza, la plurivocidad con que canta el hermosísimo diluvio de signos. No escuchar esta emoción es un método acientífico, como negar la existencia de la música de los astros, que ya había intuido entre otros Fray Luis de León mediante el conocimiento irracional de la intuición poética.

Adegas da memoria se explica desde la pasión que habita el yacimiento: la confluencia emocional de la memoria vecinal, de la escucha, de la búsqueda de lo aparentemente invisible que acaba manifestándose en formas pétreas, óseas, metálicas, en todos los lenguajes de lo humano y lo telúrico. Lo sublime intraducible 
porque está por debajo -bajo tierra- de los límites, y por ello puede situarse en la convergencia del tiempo mítico y el tiempo histórico, uno de los grandes hallazgos de este proyecto: Una pequeña comunidad rural del presente se reencuentra con sus convecinos del año mil, cuando cruzó su cielo un cometa y lo bordaron unas manos en un tapiz de Bayeux.

La verdad es belleza y la belleza verdad. Keats decía que solo eso conocemos y que con eso nos basta (Oda a una urna griega). Podemos preguntarnos entonces qué es lo que vemos cuando vemos un resto arqueológico: vemos lo que hemos sido a través de otros, sí, pero sobre todo vemos lo que somos. Y es bello porque es verdadero el amor con que acariciamos el fósil que nos explica y nos comunica con el más allá de nuestra intrahistoria. Y es verdadero porque es bello.

El canto de los pájaros se explica por la existencia de un órgano misterioso y único en la fisiología animal: la siringe, una cavidad cartilaginosa entre el pulmón y la tráquea. Quizás se trate de un órgano heredado de la época en que los pájaros eran dinosaurios: un resto fósil que canta al mundo tal vez desde una voz inextinguible del cretácico. La arqueopoesía trabaja con estas herramientas. Sin duda estos hallazgos harán que habitemos con pasión el yacimiento.

\section{Oralidad, multivocalidad y paisaje}

Through working with the debris of the past, archaeology can avoid the temptation of ventriloquism and adopt a more modest yet crucial mission: let the void of the unrepresentable open.

(González-Ruibal et al. 2011).

Esta arqueopoesía del paisaje es también una Arqueología de Urgencia. Tras un siglo de sangría demográfica, la pequeña parroquia de Vilachá (formada por las aldeas de Abelaira, Trasmonte, A Igrexa y Vilachá) contaba en el año 2000, según el censo oficial, con 89 vecinos empadronados. En enero de 2019 se contabilizan 44 habitantes. Por lo tanto, en veinte años la población se ha reducido a la mitad. Cuando hablamos de los últimos campesinos y campesinas de Europa no estamos exagerando. Estos hombres y mujeres sostienen un idioma milenario, el gallego ${ }^{6}$, que desde el siglo

\footnotetext{
${ }^{6}$ Todas las personas entrevistadas en Adegas da Memoria emplean su lengua materna. Los autores hemos traducido al castellano estas entrevistas para incorporar citas textuales en el presente artículo.
} 
$\mathrm{XVI}$ sobrevivió como habla de las clases populares. Siguen leyendo su paisaje de acuerdo con la cartografía simbólica heredada, que nada tiene que ver con las áreas de protección, los bienes culturales o la concentración parcelaria. En un espacio agrario tan humanizado como este, esta gente preserva como una especie en extinción (como ellos mismos) la microtoponimia, las leyendas, el recuerdo de la manera tradicional de habitar y trabajar la Ribeira antes de la ruptura de la década de 1960, protagonizada por los embalses, la emigración (Madrid, Barcelona, Bilbao, Europa) y la mecanización del campo. Por todo ello es tan importante la Historia Oral. Evidentemente no somos pioneros en este sentido. Cabe señalar que la investigación contemporaneísta gallega ha prestado atención a las fuentes orales, al menos desde la década de 1980. Desde la Universidad de Santiago se desarrolló inicialmente el proyecto Historia Oral de Galicia (HISTORGA) (WOUTERS, 1990) posteriormente ampliado con Os nomes e as voces, centrado éste último en la guerra civil española y la represión franquista (FERNÁNDEZ PRIETO 2009). En nuestra área de estudio se realizaron en este sentido algunas entrevistas en la década de 1990.

En lo que llevamos de siglo XXI, el interés por la memoria oral se ha manifestado desde un enfoque más propio de la Etnografía clásica. Por un lado, los vecinos entran en el relato oficial como suministradores de información valiosa para localizar y catalogar yacimientos arqueológicos (AYAN, 2005). Por otro lado, suministran anécdotas y objetos para ilustrar centros de recepción de visitantes, aulas didácticas o ecomuseos, normalmente habilitados en espacios arquitectónicos de la Alta Cultura (antiguos palacios y conventos desamortizados). Esta perspectiva fosilizante también llegó a Vilachá, en donde se intentó convertir una de las bodegas en una especie de Museo. En el marco de nuestro proyecto hemos reconvertido esa estancia oscura y llena de telarañas en un Cinema Paradiso, en un espacio vivo en donde debatimos con la comunidad local, estrenamos capítulos del documental Adegas da Memoria e impartimos adegaferencias. 


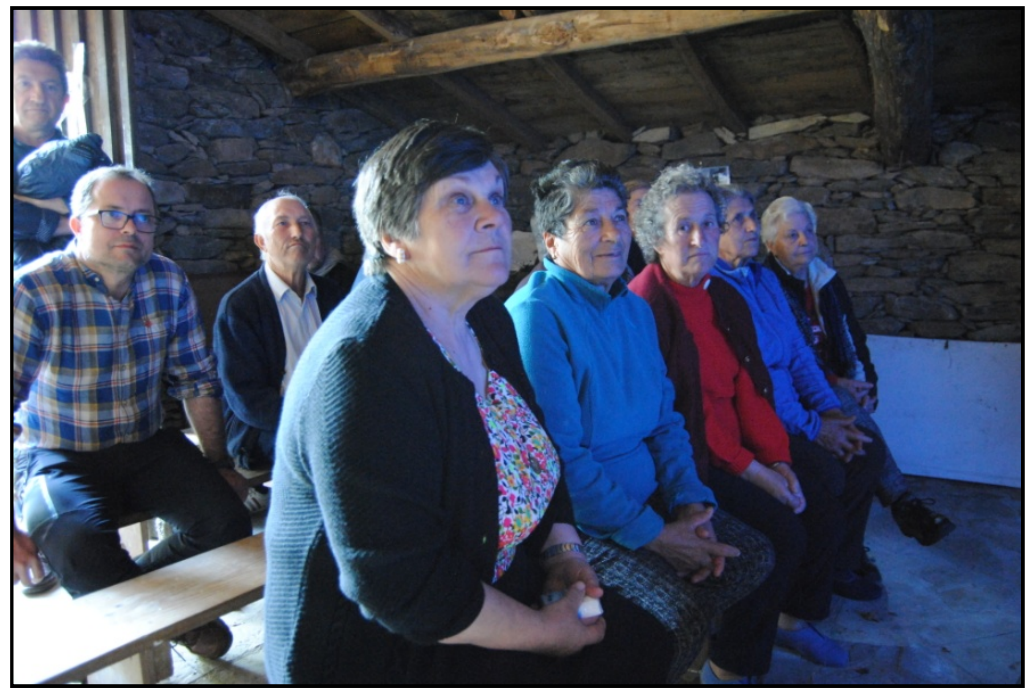

Figura 3. Estreno en la bodega-museo de la primera temporada de la webserie Adegas da Memoria, protagonizada por los vecinos y vecinas de Vilachá.

Para nosotros, los vecinos y vecinas de Vilachá no son meros reproductores de audio o informantes colonizados. Empleamos la Historia Oral como herramienta, no solo para registrar un mundo que desaparece, sino también para dar voz a aquéllos y aquéllas a los que se ha arrojado a los márgenes del discurso oficial. A partir de la materialidad del pasado (restos arqueológicos) y la memoria oral queremos devolver el protagonismo a esta gente, que sea ella quien nos hable de su propia historia, de su relación con el paisaje y los antepasados, que nos interpele y nos avance sus perspectivas de futuro. Desde estos parámetros, propios de cualquier Arqueología indígena actual, llevamos a cabo entre febrero y marzo de 2019 un total de 30 entrevistas, escuchando a la práctica totalidad de la comunidad. Los encuentros con estas voces ceibes fueron grabados por nuestros compañeros de la productora Nas Beiras y constituyen la base que sostiene el hilo argumental de la serie documental Adegas da Memoria, de la que se han emitido ya dos temporadas (pueden verse en abierto en Vimeo).

Tras unos años de reivindicación de la multivocalidad y de cierto relativismo cultural (AYÁN et al., 2012), estamos viviendo ahora un momento en el que se comienza a reclamar de nuevo la autoridad del saber científico y a denunciar las derivas populistas de la práctica de la arqueología pública y comunitaria (GONZÁLEZRUIBAL et al. 2018). No somos ventrílocuos es el subtítulo genial de una buena crítica en este sentido (RIVOLTA et al., 2014). En nuestro caso, no tenemos dudas al respecto y, con ironía, seguimos el consejo de la UNESCO. Para cualquier declaración de Patrimonio de la Humanidad, esta institución global exige contar: 1. con las 
comunidades que construyen, habitan y gestionan esos paisajes, y 2 . con evidencias empíricas, contrastadas y rigurosas que sostengan una lectura histórica de la genésis y evolución de ese paisaje. Ninguna de estas dos cosas se da en toda la Ribeira Sacra en la actualidad. Así pues, Adegas da memoria es revolucionario sin quererlo. Nuestra arqueopoética parte del mito, de la ciencia y de las voces de la comunidad (entendida aquí como parroquia de Vilachá) y así se refleja en la webserie, que se estructura en cuatro bloques temáticos: La Humanidad que habita el Patrimonio (la visión de los vecinos), Os Conventos (el proceso de excavación de este yacimiento por el equipo científico), los pataos (sigue el proceso de las primeras dataciones científicas de las terrazas de cultivo de la Ribeira Sacra) y las Adegas (en el que se estudia mediante metodología de Arqueología de la Arquitectura un conjunto de bodegas tradicionales). De la arqueopoética a la arqueoética. Adegas da Memoria no pretende sólo documentar sino también ser propositivo. Reivindicamos un modelo de gestión humanista basado en la dignificación de aquéllos y aquéllas que construyeron y mantienen el paisaje arribeirado,en el que el centro esté ocupado por las personas y no por las corporaciones, los expertos o los políticos. En la línea de la arqueología simétrica pretendemos superar así dicotomías acuñadas por la Modernidad como rural vs urbano, cultura popular vs alta cultura o tradición vs modernidad (WITMORE, 2006; OLSEN, 2007).

\section{Memorias aterrazadas y comunidades resilientes}

En algún momento yo creo que me van a nacer raíces.

Purificación Díaz Ferreiro (46 años).

Cabe buscar el origen de la Ribeira Sacra como paisaje imaginado en la consolidación del Estado-Nación español liberal en la segunda mitad del siglo XIX. En realidad, es el resultado de la confluencia de diversos factores de índole ideológica, entre los que debemos reseñar, el influjo del Romanticismo y su interés por el pasado medieval (VILLARES, 2015), la creación del concepto de patrimonio histórico-artístico y de las primeras instituciones obligadas a preservar las ruinas (entre ellas las ruinas de conventos y monasterios desamortizados) (FILGUEIRA, 1948; ADÁN, 1997), el desarrollo del nacionalismo español (NÚÑEZSEIXAS 2018) y el peso del conservadurismo católico en el anticuarismo y en el propio regionalismo gallego (ACUÑA, 1981). Este totum revolutum fue el caldo de cultivo para que intelectuales de 
la talla de Emilia Pardo Bazán y Joaquín Arias Sanjurjo asentasen el tópico historiográfico de la Ribera Sagrada, un paisaje cristiano primitivo repleto de eremitorios en donde supuestamente se refugiaron visigodos y mozárabes, exponentes de la tradición genuinamente española, a diferencia del Císter francés (ARIAS SANJURJO, 1914).

En sus exploraciones, esta élite intelectual urbanita hace mención a los paisanos y paisanas, retratados con tintes pintorescos, empleados como auténticos sherpas y conceptualizados como repositores de las esencias patrias. Se forja así un paisaje nacionalcatólico (ALARES, 2017) que tendrá éxito a posteriori, siendo recreado a nivel turístico por el fascismo primero y por los gobiernos autonómicos gallegos ya en democracia. En ambos períodos jugó un papel fundamental Manuel Fraga Iribarne, ministro franquista de Información y Turismo y después presidente de la Xunta de Galicia (1989-2005) (PACK, 2009).

La Ribeira Sacra es construida, por tanto, partiendo de un marco ideológico concreto y al margen de las comunidades locales. La tradición oral solo sirve para recrear lo que se ha dado en llamar viticultura heroica y para recuperar algún ser mítico folklórico, como los xacios y las xacias (mezcla entre seres humanos y anfibios), que sirven de base a logotipos e imágenes de marca (CUBA et al., 2006). A su vez, la ciencia apenas cuenta tampoco en todo este proceso. Los lobbies empresariales explotan conscientemente un pasado romano inexistente y los humanistas al servicio de las administraciones remarcan el carácter contemplativo, espiritual, escenográfico, de este mar interior de Galicia, del territorio europeo con la mayor concentración de arte románico de Europa (FERNÁNDEZ CASTIÑEIRA, 2012; NÁRDIZ, 2016). Nada se habla de la coerción feudal, del impacto crítico de los proyectos totalitarios del franquismo ni de la resistencia del campesinado. Las visiones de las comunidades locales podrían comprometer esta narcotización del pasado, bien presente en el relato oficial que sostiene la candidatura a Patrimonio de la Humanidad (GOY, 2019). Contra este relato hegemónico, la tradición oral no solo activa narrativas contrahegemónicas, sino que también es capaz de guiar a la propia investigación científica.

\section{El pasado mítico de la Ribeira}

Los mitos eruditos no aportan nada al conocimiento de este paisaje cultural, si bien se han ido popularizando. Todo el mundo cree que Nerón bebía vino de Amandi en jarras hechas en Gundivós, una aldea alfarera de la zona. Por el contrario, el 
patrimonio inmaterial de los vecinos y vecinas de Vilachá nos acerca a toda una fenomenología del paisaje (TILLEY, 1994) y nos aportan claves interpretativas para indagar sobre el pasado y excavar los diferentes estratos de la memoria colectiva. Un buen ejemplo es el testimonio de Juana Guntiñas (85 años):

\begin{abstract}
Los mouros ponían las joyas al sol el 24 de junio. Venía un señor de la zona de Lor, y que vio tantas joyas hasta que las cogió. $Y$ ahí en el puente de Rairos que dio un golpe en la tierra y que se abrió una puerta y aquel señor se quedó a dormir aquella noche con los mouros, y que el jefe mouro decía: me huele a gente humana. No soy yo que vengo de estar con ellos. Había una sorda aquí que contaba que había una niña llamada Pepita, que desapareció esa neniña, y la buscaban gritando Pepiña, Pepiña, y que una voz contestaba Pepiña fue comida por una eiriña. Esas son cosas que he escuchado yo a nuestros antepasados. Los curas eran los que hacían todas estas cosas, tiraban sal en el monte, en el sitio en el que querían hacer una capilla, y que iban las cabras y la lamían ¡Ay este sitio es santo!, aquí hay que hacer una capilla, y eran los curas los que procesionaban todo eso, y esto es lo que le puedo contar. Yo lo que siempre oí de A Capilla, antes de la fiesta, en aquel entonces era el San Marcos el que se escapaba, e iban a recogerlo en la procesión y lo traían a la iglesia, y el San Marcos se volvía a escapar, eso es lo que se dijo siempre. Cuando dejó de haber gente se pasó la fiesta para el 7 de agosto, día del patrón San Mamed, que es cuando hay gente. Decía mi padre que desde que se acabaron las bocas negras (las escopetas) todo eso dejó de existir.
\end{abstract}

Los mouros son seres míticos que habitaron el noroeste de la Península lbérica antes de la llegada del Apóstol Santiago. Viven bajo tierra y guardan tesoros en monumentos prehistóricos visibles en el paisaje como castros y túmulos megalíticos. Las mouras son muy atractivas e intentan engañar a los paisanos (LLINARES, 1990). Son muy semejantes a otros seres que se conservan en la cultura popular de la Europa atlántica como los Mairiak vascos, los Korrigans bretones o los elfos escandinavos. Los mouros se vinculan siempre a Galicia a sitios encantados, señalizan simbólicamente lo que los científicos llamamos yacimientos arqueológicos (LLINARES, VÁZQUEZ, 1990). Juana nos adentra en la temporalidad del paisaje (INGOLD 1993), nos esboza el espesor histórico de un lugar conocido como A Capilla. Actualmente hay ahí un mirador para contemplar la belleza estática del cañón del río Sil. Lo que hemos descubierto, gracias a las mujeres de Vilachá, es que ahí hay restos de un dolmen, un enterramiento megalítico prehistórico que posteriormente fue cristianizado. No es casual que el santo patrón de la parroquia se escape de la iglesia y vuelva a su sitio. Esta creencia popular se da en muchos sitios de Galicia y lo que estamos viendo desde la arqueología es que esos relatos remiten siempre al origen de la propia comunidad (AYÁN, 2005). La fiesta se hacía en un bosque en esa zona, como señalaba O' Morales: "Un año que no llovía, los curas llevaron el santo hasta allí 
a aquellos castaños que son nuestros, decidieron hacer una reliquia o como le quieran llamar, fueron con la procesión hasta San Marcos o A Capilla, es todo lo mismo".

Los vecinos diferencian perfectamente la ritualidad oficial católica de sus prácticas comunitarias, las cuales siguen apropiándose, aunque sea ya solo en el recuerdo, de espacios que remontan su capital simbólico a épocas altomedievales, cuando no prehistóricas.

Dentro de esta de una geografía ancestral (EDMONDS, 1999) los seres míticos cobran un especial protagonismo. Aquí entra de lleno la figura del Aláparo, un ser monstruoso, una suerte de cíclope, caníbal y depredador sexual (NOVO, 2020). Así nos lo cuenta Benigno González O’ Madera (99 años):

\begin{abstract}
A la abuela de la Matilde se la llevó un hombre que tenía una pierna sola, que venía de O Eivedo, le llamaban el Aláparo, hace mucho tiempo de eso, yo no lo ví. Andaba por el monte, con una pierna sola. Yendo para A Capilla hay un prado en el que nacían juncos, y dijeron que los vecinos enterraron ahí al aláparo, en donde lo mataron, cerca del roble de A Chá.
\end{abstract}

Los mouros o los aláparos no son para esta gente seres imaginarios; realmente existieron y hay testimonios concluyentes, como el de Magdalena Defente Mencia, Milucha (78 años):

\begin{abstract}
Ellos persiguieron al aláparo con unas horquillas y lo cogieron ahí y lo enterraron ahí. Mis padres me contaron que el aláparo ese secuestró a una mujer de mi familia, bisabuela o tatarabuela, no sé bien, y la llevó por ahí abajo a vivir, por la Ribeira, y le hizo un hijo. Y después él no sé a dónde fue, ella escapó y se fue a la casa en donde vivo yo. $Y$ el nieto, que iba subido al cuello del abuelo, le decía al abuelo qué cuello más bueno tienes para hacer callos. Se conoce que se parecía al aláparo. Y después ya no sé más del aláparo.
\end{abstract}

Matilde López Álvarez (78 años), descendiente de aquella chica raptada, cerró así, arqueopoéticamente, la conversación: "Eso es muy antiguo. Ella lo envió a buscar laurel a la ribeira y aprovechó ella y se escapó."

Como en el caso de los xacios del río Miño, aquí en la ribeira de Vilachá se dio también un cruce de razas entre cristianos y monstruos. La gente de Vilachá enseña al visitante el roble de A Chá, el lugar de enterramiento del cíclope. Castaños, robles, santos, aláparos, dólmenes, capillas. Nada de esto se cuenta al turista que se enfrenta al Sil en el mirador, a un paisaje ahistórico, mudo, silencioso. La sinaléctica cita, únicamente, las especies vegetales que cubren la Ribeira. Geodestino. Ecosistema. Microclima. Patrimonio de la Humanidad. 


\section{El paisaje semantizado: conventos, peñascos, eremitas y frailes}

El río Sil es uno de los principales ríos del NW de la Península lbérica, el Finis Terrae de la Europa continental. Nace a casi 2000 m de altitud en las estribaciones de la Cordillera de Cantábrica y atraviesa las comarcas naturales de Babia, Laciana, El Bierzo, La Cabrera y Valdeorras, para servir de límite entre las tierras de Lemos y Caldelas, antes de desembocar en el río Miño. Debido a la naturaleza montañosa de toda esta región geográfica, desde el Paleolítico, el valle del Sil sirvió de vía de tránsito natural para acceder a Galicia desde el Este. Como en otras zonas atlánticas europeas, durante la prehistoria reciente, las comunidades locales llevaron a cabo ofrendas en sus aguas, sobre todo, espadas de bronce, como las localizadas en este tramo del cañón, a veces escondidas en grietas de peñas y roquedos bien visibles en el paisaje (LÓPEZ CUEVILLAS, 1955; GONZÁLEZ GARCÍA, 2009). Durante la Edad del Hierro (primer milenio antes de nuestra era) el Sil sirvió de frontera política entre diferentes grupos en la Edad del Hierro. Este carácter fronterizo fue reconocido por los romanos, que eligieron el río como límite entre los conventus lucense y bracarense, dentro de la provincia de Gallaecia. El flumen Syle fue una especie de El Dorado para los romanos, quienes regaron su lecho de explotaciones auríferas en el período altoimperial (siglos I-II de nuestra era). El cañón del Sil no fue habitado por grupos humanos hasta la plena cristianización de Galicia durante el reino suevo. En el siglo VI se ubica el origen de los que parecen ser los primeros eremitorios. Una nueva etapa en la apropiación simbólica de este espacio. Como podemos comprobar, se trató de una peculiar cristianización, en parte fallida, ya que llegaron a nuestros días los relatos paganos sobre aláparos y mouros.

Los siglos altomedievales conforman una época oscura, previa a la colonización cisterciense del siglo XII. En ese período en el que se desarrolla el reino de Galicia, proliferaban eremitorios, pero también monasterios dúplices, fundados por familias nobles y regidos por la regla de San Fructuoso. En ellos convivían monjes y monjas y se preservan prácticas prerromanas y heréticos ritos priscilianistas (RODRÍGUEZ CASTILLO, 2005). Apenas existe documentación sobre estos siglos oscuros. Dejando al margen los mitos eruditos, debemos echar mano de la tradición oral y de los restos arqueológicos. De nuevo, los vecinos y vecinas de Vilachá acuden al rescate. Ellos y ellas saben que todo era de los monjes, las bodegas y las viñas, durante cientos de años, hasta que llegó la desamortización en el siglo XIX. EI monasterio benedictino de San Vicenzo do Pino controlaba la Ribeira de Lagares 
mientras el convento cisterciense de Santa María de Montederramo dominaba O Eivedo y Val do Frade. En este último, la comunidad de Vilachá conserva una pequeña parcela en propiedad a la que denominan Os Conventos. Así nos lo cuenta Juana:

Yo lo que he oído es que había el convento y la Santa Inquisición. Y que había, que castigaban mucho a la gente, que tenían una sierra, los montaban en una sierra a y que los serraban en vida hasta que morían así. Y que a otros que les ponían agua en la cabeza, una gotera y que morían así. Los que tienen viñas ahí todavía encuentran cavando cosas que tienen relación con el convento de ahí. Las bodegas de Vilachá eran de los monjes, que fueron los que cocían el vino abajo en los conventos y que lo traían aquí. Eso fue lo que se contó siempre.

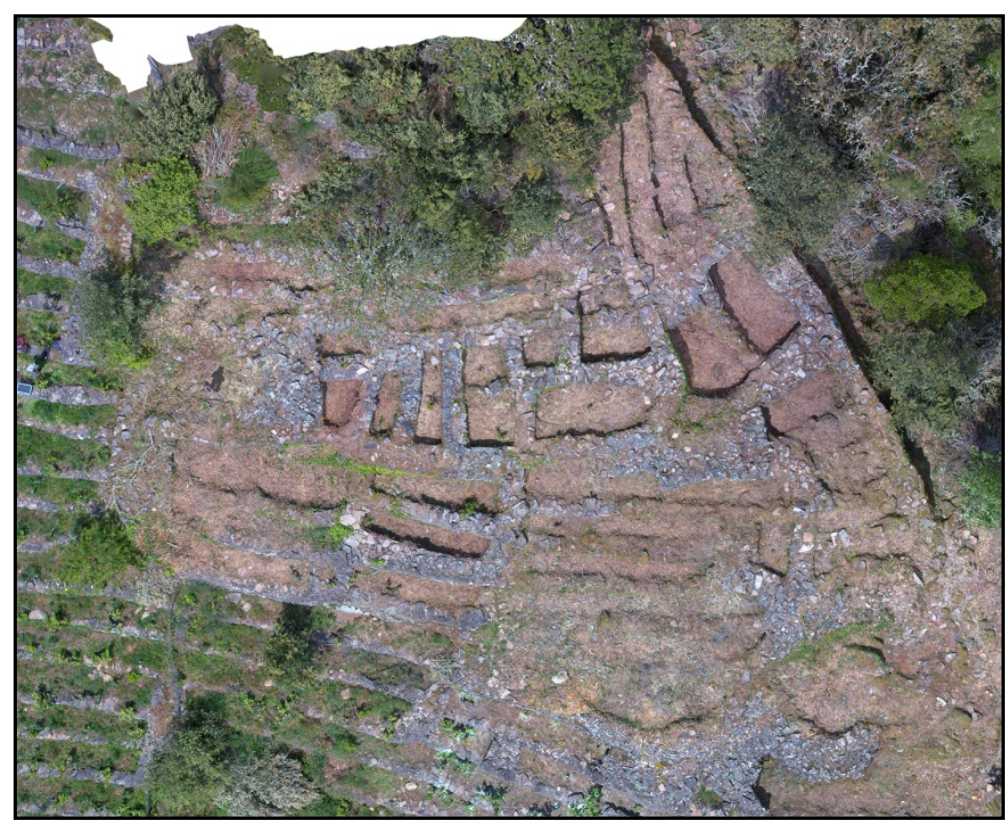

Figura 4. La Ribeira como geografía ancestral. Fotografía aérea del yacimiento arqueológico de Os Conventos, al iniciar la excavación de mayo de 2019 (Fotografía de Manoel A. Franco).

Si el mito erudito nos habla de los esclavos que Roma utilizó en las minas de oro y las terrazas vinícolas, la tradición oral asimila y reinterpreta leyendas decimonónicas románticas que calaron hondo, siguiendo la consigna antifeudal liberal. Así, es común que se cite a la Inquisición o se hable incluso de una cárcel, como nos recuerda José Aira López, O’Bato (70 años):

El lugar en donde estamos era la cárcel y aquí decían nuestros antepasados que en vez de pagar en dinero pagaban en dinero pagaban en diezmos, le llamaban así, entonces el tipo que estaba en Vilachá en sus propiedades y no pagaba eso iban por él y lo traían a la cárcel y aquí lo tenían.

Es cierto que en el Antiguo Régimen los monasterios ejercían el poder judicial en su jurisdicción, como cualquier otro señor feudal. Los antepasados desde luego, como se demuestra en los documentos medievales, estaban obligados no solo a pagar 
una renta, sino también a obedecer al fraile, a reparar los muros y terrazas y a trabajar como siervos cuando fuesen requeridos (LORENZO, PÉREZ, 2016).

Como en el caso de A Capilla y el bosque de San Marcos, la tradición oral nos trae a un sitio concreto, que no existe oficialmente ya que no está catalogado ni inventariado por los servicios de protección del patrimonio. Sin embargo, la gente de Vilachá sabe que ese sitio es importante, y ellos mismos encontraron evidencias arqueológicas. Como recuerda María José Aira Pumar (40 años):

\begin{abstract}
El motivo de que este convento desapareciese pues la verdad es que no sabemos, generaciones atrás nadie se acuerda de la edificación en uso. Todo el mundo habla de restos y de ruinas. Vinculado al monasterio de los conventos a hay un lugar muy cerca que toda la gente del pueblo conoce como cárcel. El uso que le daban pues no lo sabemos si era sacar mano de obra para construir las muras, las bodegas, no lo sabemos.
\end{abstract}

La Asociación de Vecinos decidió que excavásemos en este lugar, y no en ningún otro. Podríamos haber ido al Castrelao, el poblado fortificado de la Edad del Hierro, también habitado por mouros, pero no. Así pues, en mayo de 2019 llevamos a cabo una excavación arqueológica en el paraje de Os Conventos y, nuevamente, el pueblo tenía la Razón. Encontramos un enterramiento secundario y evidencias de otras tumbas, que hemos datado por C-14 en el siglo X. Estas son las evidencias más antiguas hasta el momento, de un conjunto de estructuras que estuvieron ocupadas a lo largo de la Edad Media, como así lo demuestran los restos cerámicos y los hallazgos numismáticos. Os Conventos tiene su origen en un antiguo eremitorio, después convertido en pequeño convento (San Martiño de Piñeira). En el siglo XII el emperador Alfonso VII dona este cenobio al monasterio cisterciense de Montederramo. La Orden del Císter es la responsable de la colonización vinícola de esta ribeira. De hecho, reconvierte el pequeño convento en una granja (A Granxa de Piñeira), a cargo de la cual está un fraile granjero, el frade que dio nombre al propio Val do Frade (LORENZO, PÉREZ, 2016). Serán estos monjes blancos los que introduzcan la Ribeira en una economía de mercado y la orienten a la producción. Pero no solo eso. El Císter acaba con la regla de San Fructuoso y con todo ese paisaje simbólico altomedieval sembrado de creencias paganizantes, prerromanas y priscilianistas (PORTELA, 1981; ANDRADE, 2000).

La explotación vinícola de entonces y la industrial de ahora ha destruido la gran mayoría de yacimientos y vestigios de aquella época enigmática y oscura. En cambio, en Vilachá, ubicada en la periferia de la periferia, todavía se conservan relictos de aquel antiguo paisaje sagrado. Nuevamente la tradición oral ha sido nuestra mejor 
guía. El mito no está reñido con la ciencia. Los vecinos y vecinas (esas voces subalternas) sabían, porque se lo escucharon a sus abuelos, y sus abuelos a sus abuelos, que en Os Conventos podría estar el origen de la comunidad, en esa Ribeira en la que vivían los mouros y los aláparos. La Historia Oral arroja luz sobre los Siglos Oscuros.

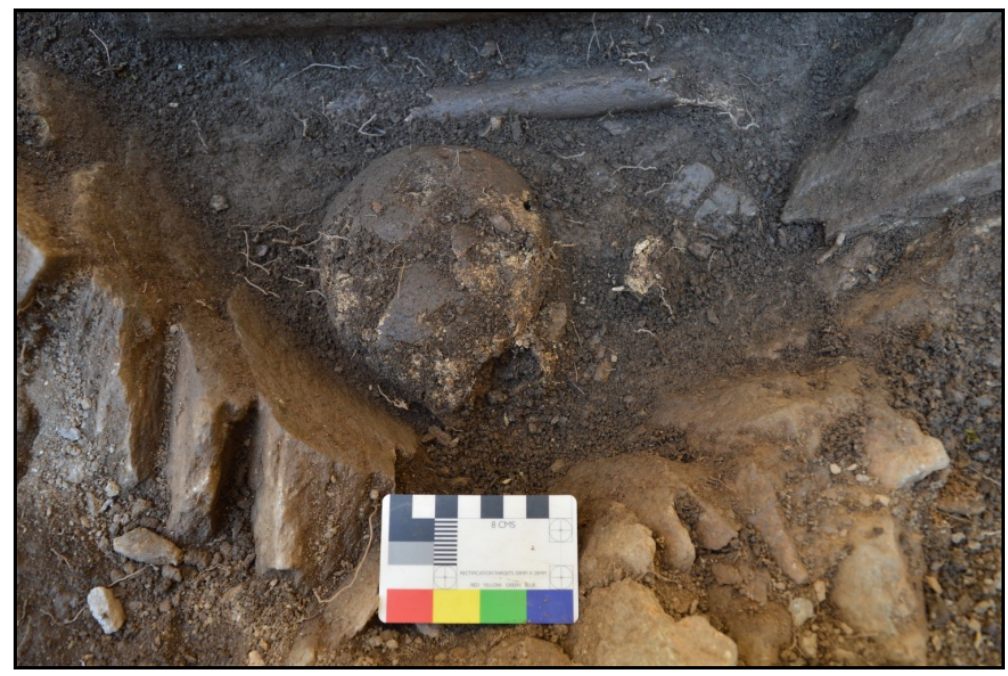

Figura 5. A la busca de los abuelos. Enterramiento secundario del siglo $\mathrm{X}$ documentado la excavación arqueológica de Os Conventos (Fotografía de Xurxo Ayán).

\section{El trauma del fascismo}

Eso son cosas de política, de antes de la guerra. Mi padre no estuvo en la guerra, que estaba escondido. Emilio Prieto, O'Petoco (80 años)

El mundo del vino, la vida tradicional de la Ribeira, las leyendas, la religiosidad popular definen una estratigrafía cómoda dentro de ese yacimiento inmenso que es la memoria colectiva de la vecindad de Vilachá. Sin embargo, al excavar en ella como arqueólogos psicoanalistas, somos capaces de documentar interfaces, grietas que suturan todavía traumas del pasado. Esto es lo que ocurre con la guerra civil y la represión fascista. Un único episodio de la webserie generó polémica en el seno de la comunidad, y ese fue el dedicado a lo que en España se conoce como la memoria histórica ${ }^{7}$. En las primeras tomas del capítulo, durante unos segundos ondea al viento la bandera de la II ${ }^{a}$ República Española (1931-1939). Este detalle no pasó inadvertido para algún vecino que no veía bien mezclar la política y el pasado de la parroquia. Esta actitud se explica por la sangrienta represión llevada a cabo por paramilitares

\footnotetext{
${ }^{7}$ https://adegasdamemoria.com/2019/04/25/ep-4-a-verdade-viva/
} 
fascistas (falangistas) desde el verano de 1936 (AYÁN, 2020). Aquellos tiempos llevan a recordar comportamientos de todo tipo, que rompen el marco de convivencia establecido por el ethos comunitario. Hubo delatores y perseguidores, pero también una notable solidaridad intracomunal que llevó a proteger a republicanos perseguidos. Juana recuerda:

\begin{abstract}
Si nuestro perro ladraba una vez, todo en silencio, si el perro daba más de un ladrido, cada uno escapaba a donde podía. Había un pajar allí abajo, y allí cogían un poco de paja del pajar, la echaban a la pared y al suelo y dormían como podían. Desde aquel día yo ya no volvía a esta casa, porque aquí estaba con los tíos. Ya fui a casa de mi padre. Mi padre que tenía un molino y allí les llevaba comida cuando andaban escapados, y les hacía lumbre y les secaba la ropa, en el invierno. Un día iba mi madre a llevarles comida y venía una de los contrarios venía también del molino y mi madre se echó al monte haciendo que se iba, que era cuando les iba a llevar comida. Eso es real porque pasó aquí.
\end{abstract}

Este trauma colectivo sepultó con un silencio sepulcral el recuerdo de aquel drama. Incluso llevó a modelar una imagen mítica de aquellos tiempos. En muchas zonas de Galicia los mouros de las leyendas fueron sustituidos por otros seres reales que remiten a momentos conflictos, como los franceses, los carlistas, los facciosos o los fuxidos (huidos). Todos ellos eran concebidos como distintas razas que pasaron con violencia por el país, dentro de una concepción cíclica del tiempo que rejuvenece, reactualiza y/o envejece acontecimientos y procesos históricos. Estos escapados reutilizaban abrigos rocosos, cuevas e incluso yacimientos arqueológicos, como tal hacían los mouros (APARICIO CASADO, 1999). Así tenemos testimonios en Vilachá de estos refugios. En palabras de Anglada y O'Morales:

Hizo una doble pared, de madera y el Pepe de Pol y todos esos, eran los que tenían la cueva en nuestro prado, por el día parecía que iban con las ovejas y llevaban la comida, y estaban allí noche y día, plantaron una viña allí del carajo, en vez de ir a la guerra se dedicaron a plantar una viña. 


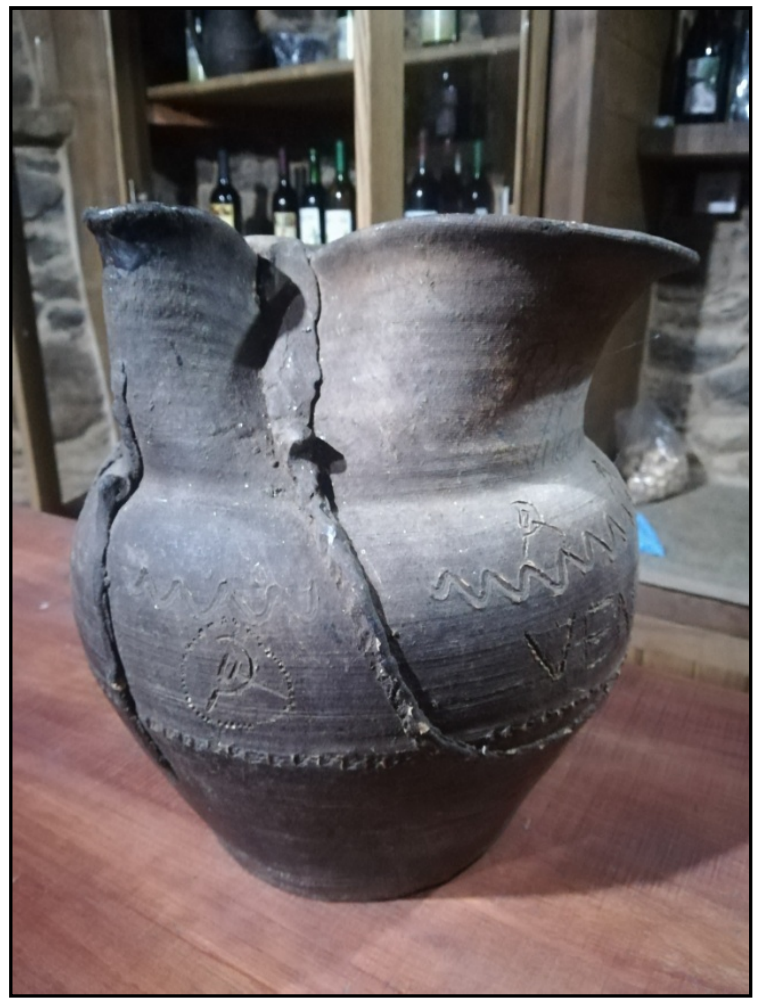

Figura 6. Resiliencia. Antigua jarra para servir vino con simbología comunista grabada. Bodega de O' Morales (Fotografía de Xurxo Ayán).

El proyecto Adegas da Memoria ha servido para sacar a la luz pública, por vez primera, estos testimonios públicos sobre la violencia ejercida por los perpetradores, a veces de manera coral y no tanto a nivel personal. Nuestro trabajo de Historia Oral en Vilachá ha permitido conocer al detalle y dignificar la memoria de dos víctimas. El primero de ellos era el maestro nacional del pueblo, Juan Abramo Dios. Podría ser perfectamente el protagonista de La lengua de las mariposas, el relato de Manuel Rivas llevado al cine por José Luis Cuerda (1999). En esta obra se resume de manera magistral la masacre efectuada por el fascismo entre los maestros, que eran un símbolo de los nuevos tiempos republicanos. O’ Madera, el más anciano de Vilachá, fue alumno de Abramo: El maestro no era de aquí. Le llamaban don Juan, pero no me acuerdo de dónde era. Lo querían matar y lo mataron por ahí por Abrence.

Su recuerdo perdura en la parroquia porque cada primavera florecen los árboles frutales que él ayudó a plantar, como recuerda Juana:

Todos los árboles frutales que había aquí, los trajo él, que era de Tui. Vino aquí de maestro. Su padre tenía un vivero. Mi padre y mi madre hablaban mucho de él. Daba muchos consejos y buenos, a fin de mes si sobra una peseta las cosas van bien, si no hay, van mal ¿Por qué lo mataron? Aún hay perales hoy de los que trajo aquel señor. 
Juan Abramo fue asesinado junto con el carpintero Odilo Rodríguez y un desconocido, en el km. 52 de la carretera de A Pobra do Brollón a Quiroga, en la cuneta de la izquierda de la carretera en dirección a Quiroga, con cabeza hacia el Sur, sobre el lado izquierdo mirando a la carretera, se hallaba vestido con pantalón y chaqueta azules, camisa blanca, corbata azul, con pinzas blancarrojas, zapatos de color, calcetines grises, cinto claro, sin que en los bolsillos se le encontrase cosa alguna nada más que un pañuelo blanco, con las iniciales J.A."”. El maestro, de punta en blanco, se disponía a iniciar el nuevo curso académico cuando fue detenido por sus asesinos. Su llegada a Vilachá en 1933 había supuesto la aplicación de innovaciones pedagógicas y una apuesta clara por la enseñanza pública y laica. Su compromiso conllevó la oposición de las fuerzas vivas del lugar y del propio cura párroco. Fue denunciado por un falangista, enamorado de la novia de Abramo, maestro como él, y que sería su sustituto en la escuela. Abramo fue destituido de su cargo tres días después de su asesinato. Sepultado en una fosa común en el atrio del cementerio de Abrence, su cuerpo fue recuperado clandestinamente por su familia y reenterrado en un nicho en el mismo lugar.

El otro personaje que hemos conseguido rescatar tuvo mejor suerte, aunque las secuelas de su cautiverio le llevaron a la muerte en 1945. Nos referimos al líder socialista Juan Tizón Herreros, alcalde de Monforte de Lemos, que se refugió durante la guerra en Vilachá, en una bodega (actualmente en ruinas) a la que él llamaba La Cueva. Aquí Tizón escribió un poemario anticlerical en gallego (ALONSO MONTERO, 2001), una obra de teatro en la que ensalza la Unión Soviética y unas memorias (LÓPEZ, 2010). Mientras tanto, las batidas de falangistas en su busca se sucedían, acompañadas de asesinatos y palizas a vecinos y colaboradores. La situación se hizo insostenible y el alcalde fue evacuado; vecinos le ayudaron a cruzar el cañón del Río Sil y se refugió en Torbeo (Ribas de Sil). Finalmente, un pastor logró sacarlo de Galicia por las montañas orensanas (por la misma ruta que seguirían años después judíos europeos y aviadores aliados) y cruzó la frontera con Portugal.

La figura del maestro asesinado por los fascistas contribuye a dignificar a las víctimas, si bien resulta conflictivo, ya que su delator era otro miembro de la comunidad que acabó ocupando cargos durante el régimen franquista. A su vez, el periplo del alcalde huido y protegido por la ley del silencio vecinal nos habla del olvido impuesto sobre ese período de nuestra historia. Gracias a Adegas de la Memoria se

\footnotetext{
${ }^{8}$ Archivo Intermedio Militar del Noroeste, Ferrol. Causa Lugo 921-1936: "Muerte violenta de Juan Abramo Dios, Odilo Rodríguez y otra que resultó desconocido".
} 
ha dado a conocer por primera vez qué pasó con Tizón entre 1936 y 1940, cuando reaparece en Oporto con una identidad falsa. Su recuerdo también es problemático en el seno de la comunidad, ya que durante su estancia tuvo un hijo con una vecina de Vilachá (él estaba casado).

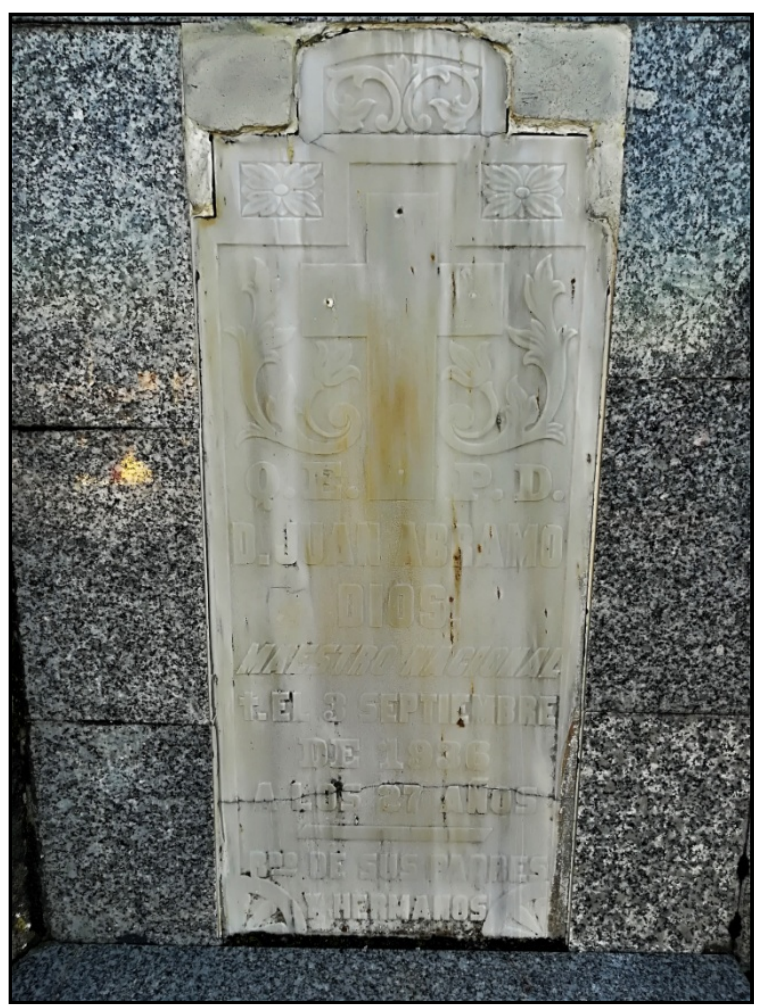

Figura 7. Lápida funeraria del maestro Juan Abramo Dios, en el atrio de la iglesia de San Xoán de Abrence (Fotografía de Xurxo Ayán).

\section{Conclusiones}

La gran escritora Emilia Pardo Bazán, aficcionada al folklore y el excursionismo, visitó en el otoño de 1887 el convento en ruinas de San Esteban de Ribas de Sil. Esta exploración fue recogida por ella en su libro De mi tierra (PARDO BAZÁN, 1888, p. 275-295). El ferrocarril, llegado a estas tierras tan solo cuatro años antes, facilitó el descubrimiento de la Galicia interior. Doña Emilia, como buena naturalista, describe de modo evocador el antiguo paisaje monástico, nos habla de las mujeres barqueras anónimas que ayudan a cruzar el Sil (río aurífero y misterioso), de los paisanos anónimos que hacen de guías y comentan en voz baja las correrías amorosas de los viejos frailes. También recogió leyendas como la del pájaro malvís cantor traído de Oriente por los eremitas. 
Casi treinta años después, la Excursión a la Ribera Sagrada (1914) del abogado Joaquín Arias Sanjurjo supuso el primer intento serio de estudiar arqueológicamente el cañón del río Sil. Buen conocedor de la historia medieval, quería ver las ruinas in situ de los antiguos cenobios eremíticos. Como si fuese un explorador africano, realizó su sueño cuando se abrió la carretera entre Monforte de Lemos y Castro Caldelas. Para moverse en este paisaje agreste se hizo con los servicios de sherpasautóctonos, paisanos que conocían los senderos más ignotos y los vados del Sil. Por supuesto, este erudito, que se autoproclamaba defensor de los intereses del agro gallego, no consignó el nombre de los guías, a los que despacha en su crónica con el calificativo de viejos campesinos animosos. Los buenos salvajes que aplaudían la llegada del ferrocarril en 1883 o la visita del joven rey Alfonso XIII en 1907 eran vistos por la élite intelectual como un elemento básico del pintoresquismo del valle de Lemos. Arias Sanjurjo hace de profeta y considera este territorio como una reserva india, en la que se conserva lo más auténtico y espontáneo del espíritu gallego, ritos, prácticas y creencias que deben ser registradas y documentadas, aunque pronto será tarde para hacerlo (ARIAS SANJURJO, 1914, p. 43).

Este uso costumbrista de las fuentes orales para acercarse a nuestro campesinado se mantuvo incólume a lo largo del siglo XX. El triunfo de los sublevados en la guerra civil en 1939 acabó con el asociacionismo agrario, consolidó las redes caciquiles e impuso el nacionalcatolicismo. En definitiva, reafirmó el carácter subalterno de unas comunidades rurales que sufrieron las miserias de la represión y la postguerra, y se vieron forzadas a la emigración. La llegada de la democracia no cambió este enfoque paternalista y colonial pero tampoco ha acabado con la resiliencia de esta gente apegada a su paisaje como las raíces de los robles. Dentro del presente proceso de patrimonialización de la Ribeira Sacra reivindicamos toda una arqueología de los pueblos colonizados (GIVEN, 2004; BRUCHAC et al., 2010). Es necesario dignificar la-manera-de-estar-en-el-mundo de los habitantes de la verdadera Ribeira, reivindicar su protagonismo como sujetos políticos y conseguir que el eco de sus voces retumbe en el cañón del Sil. Esos son los objetivos de un proyecto modesto como Adegas da Memoria, una iniciativa que combina la ciencia, el mito, la poesía, la Arqueología de la Percepción, la fenomenología del paisaje y la emoción. Porque somos lo que soñamos. El saber tiene sabor afrutado, como la memoria y las uvas mencía de la Ribeira. La vida y la vid se construyen mutuamente. Los vecinos y vecinas de Vilachá son los protagonistas de esta historia, la humanidad que habita el patrimonio. 


\section{Agradecimientos}

El Instituto de História Contemporânea cuenta con financiación pública a través de la Fundação para a Ciência e a Tecnologia, I.P., proyectos UIDB/04209/2020 y UIDP/04209/2020.

A todos los vecinos y vecinas de San Mamede de Vilachá de Salvadur. A lago Seoane y Rudá Cordaro (productora Nas Beiras S.L.). A todo el equipo arqueológico de la excavación de Os Conventos. A la profesora Paula Godinho (IHC, FCSH, Universidade Nova de Lisboa) que nos animó a presentar nuestro proyecto Adegas da Memoria en el I Congresso Internacional Usos do Passado, Memória e Património Cultural (Arquivo da Torre do Tombo, Lisboa, noviembre de 2019). Este artículo es una versión ampliada de aquella ponencia.

\section{Bibliografía}

ACUÑA CASTROVIEJO, F. "A arqueoloxía na obra de López Ferreiro". Cuadernos de Estudios Gallegos, 32, 1981, p. 57-80.

ADÁN ÁLVAREZ, G. "La Comisión de Monumentos de Oviedo (1844-1978): Génesis y desarrollo", en Mora, G. y Díaz-Andreu, M. (eds.): La cristalización del pasado: génesis y desarrollo del marco institucional de la Arqueología en España: 259-264. Málaga: Universidad de Málaga, CSIC, 1997.

ALARES LÓPEZ, G. Políticas del pasado en la España franquista (1939-1964). Historia, nacionalismo y dictadura. Madrid: Marcial Pons, 2017.

ALONSO MONTERO, X. "Seis cregos escollidos (Versos Divinos), poemario escrito por Juan Tizón Herreros, no exilio e no silencio, nos anos da Guerra Civil". Madrygal: Revista de estudios gallegos, 4, 2001. p. 9-24.

ANDRADE CEMADAS, J. M. Monxes e mosteiros na Galicia medieval. Biblioteca de Divulgación, 18. Santiago: USC. $1^{\text {a }}$ reimpresión, 2000.

APARICIO CASADO, B. Mouras, serpientes, tesoros y otros encantos. Mitología popular gallega. Cadernos do Seminario de Sargadelos, 80. Sada: Ediciós do Castro, 1999.

ARAGUAS, V. Voces Ceibes. Vigo: Edicións Xerais de Galicia, 1991.

ARIAS SANJURJO, J. "Una aproximación a la Ribera Sagrada”. Boletín de la Comisión Provincial de Monumentos de Orense, tomo V, n 97, 1914, p. 41-47.

AYÁN VILA, X. M. "Os castros despois dos castros: Un espazo simbólico na paisaxe tradicional galega", en Ballesteros Arias, P. (ed.): Encontros coa Etnografía. Noia: Toxosoutos, 2005, p. 63-136. 
AYÁN VILA, X. M. "Etnoarqueología de la represión fascista en A Pobra do Brollón (Lugo, España) (1936-1949)". Vestígios. Revista Latino-Americana de Arqueologia Histórica, 13, 2020, p. 38-61. Disponível em https://doi.org/10.31239/vtg.v2i13.15345, acesso em Dez 2020.

AYÁN VILA, X. M., GONZÁLEZ VEIGA, M., y RODRÍGUEZ MARTÍNEZ, R. M. "Más allá de la arqueología pública: arqueología, democracia y comunidad en el yacimiento multivocal de A Lanzada (Sanxenxo, Pontevedra)". Treballs d'Arqueologia, 18, 2012, p. 63-98. Disponível em https://ddd.uab.cat/pub/tda/tda a2012n18/tda a2012n18p63.pdf, acesso em Dez 2020.

AYÁN VILA, X. y SEÑORÁN MARTÍN, J. "Together Hand in Hand Towards Extinction: The Patrimonial (Neoliberal) Guardianship of Rural Communities", en Aparicio Resco, P. (ed.): Archaeology and neoliberalism: Madrid: JAS Editorial, 2016, p. 47-58.

BENJAMIN, W. Imágenes que piensan, Obras, libro IV, vol. 1. Madrid: Abada, 2010.

BRUCHAC, M. M.; HART, S. M. e WOBST, H. M. Indigenous Archaeologies. A Reader on Decolonization. Walnut Creek: Left Coast Press, 2010.

CHÁVARRI PÉREZ, S. A construcción dos saltos do Sil. 1945-1965. Ourense: Deputación de Ourense, 2010.

CUBA, X. R.; REIGOSA, Carlos e MIRANDA, X. Diccionario de los Seres Míticos Gallegos. Vigo: Xerais, 2006.

EDMONDS, M.Ancestral Geographies of the Neolithic: Landscapes, Monuments and Memory. London: Routledge, 1999.

FERNÁNDEZ CASTIÑEIRAS, E. "Cielo, agua y piedra. La fe sobre la que se construyó la Ribeira Sacra (Ourense)", en Lozano, Ma. P., Méndez, V. y Asenjo, E. (coords.): Paisajes modealdos por el agua: entre el arte y la ingeniería: Cáceres: Editora Regional de Extremadura, 2012, p. 313-36.

FERNÁNDEZ PRIETO, L. "As vítimas, os nomes e as voces, el projecte de creació d'un Arxiu Públic de la Memória", en Segura, A., Mayayo, A. y Solé, Q. (eds.): Fosses comunes i simbología franquista: València: Editorial Afers, 2009, p. 283-298.

FILGUEIRA VALVERDE, J. "Don Casto Sampedro y su Sociedad Arqueológica". El Museo de Pontevedra, V: Pontevedra, 1948, p. 16-49.

GIVEN, M. The archaeology of the colonized. London and New York: Routledge, 2004.

GODINHO, P.O futuro é para sempre - Experiência, expectativa e práticas possíveis. Lisboa/Santiago de Compostela, Letra Livre/Através Editora, 2017.

GONZÁLEZ GARCÍA, F. J. "Between Warriors and Champions: Warfare and Social Change in the Later Prehistory of the north-western Iberian Peninsula". Oxford Journal of Archaeology, 28(1): 2009, p. 59-76. Disponível em: https://www.academia.edu/1135707/Between Warriors and Champions Warfare and Social Change in the Later Prehistory of the North-Western Iberian Peninsula, acesso em Dez 2020.

GONZÁLEZ-RUIBAL, A.; SAHLE, Y.; AYÁN VILA, X. M. "A social archaeology of colonial war in Ethiopia". World Archaeology 43(1):, 2011, p. 40-65. Disponível em: https://digital.csic.es/handle/10261/44528?locale=en. Acesso em Dez. 2020. 
GONZÁLEZ-RUIBAL, A., ALONSO GONZÁLEZ, P.; CRIADO BOADO, F. "Against reactionary populism: towards a new public archaeology". Antiquity, vol. 92, Issue 362:, 2018, p. 507-515. Disponível em: https://doi.org/10.15184/aqy.2017.227, acesso em Dez 2020.

GOY DIZ, A. "The Ribeira Sacra: the definition of its Outstanding Universal Value", en Mario Crecente, J. M. (coord.): A future for the land: cultural landscapes, rural management and geographical information systems (Expert Workshop Ribeira Sacra, 8-9 November 2018): 98-107. Santiago de Compostela: Fundación Juana de Vega, 2019.

HAMILAKIS, Y. "Sensorial Assemblages: Affect, Memory and Temporality in Assemblage Thinking”. Cambridge Archaeological Journal, 27(1),.2017, p. 169-182. Disponível em: https://doi.org/10.1017/S0959774316000676, acesso em Dez 2020.

INGOLD, T. "The temporality of the landscape". World Archaeology, 25(2), 1993, p. 152-174. Disponível em: https://doi.org/10.1080/00438243.1993.9980235, acesso em Dez 2020.

LISÓN TOLOSANA, C. "Informantes: in-formantes". Revista de Antropología Social, 9: 2000, p.17-26. Disponível em: https://doi.org/10.5209/rev RASO.2000.v9.10784, acesso em Dez 2020.

LORENZO VÁZQUEZ, R.; PÉREZ GONZÁLEZ, M. (eds.). Colección documental do mosteiro de Montederramo. Santiago: Consello da Cultura Galega, 2016.

LLINARES GARCÍA, M. Mouros, ánimas, demonios. Madrid: Akal, 1990.

LLINARES GARCÍA, M. y VÁZQUEZ VARELA, J. M. "Señalización simbólica del territorio: la acción de los seres imaginarios", en Actas del Simposio Internacional de Antropoloxía Identidade e Territorio: Santiago: Consello da Cultura Galega, 1990, p. 97-117.

LÓPEZ, R. Juan Tizón Herreros. El pensamiento hecho palabra. Fundación Luís Tilve, Santiago de Compostela, 2010.

LÓPEZ CUEVILLAS, F. “Armas de bronce ofrendadas al río Sil”. Zephyrus, 6:, 1955, p. 234-240.

NÁRDIZ ORTIZ, C. "La Ribeira Sacra: entre el arte, la naturaleza y la ingeniería". Revista de Obras Públicas, 3576:, 2016, p. 29-40.

NOVO, O."A casa da culpa". O bosque dos cromosomas. Luzes. 16 de abril de 2020. Disponível em: https://luzes.gal/16/04/2020/opinion/a-casa-da-culpa/.acesso em Dez 2020.

NÚÑEZ SEIXAS, X. M. Suspiros de España: El nacionalismo español 1808-2018. Barcelona: Crítica, 2018.

OLSEN, B. "Genealogías de la Asimetría: ¿Por qué nos hemos olvidado de las cosas?" Complutum, 18: Madrid, 2007, p. 287-91. Disponível em: https://revistas.ucm.es/index.php/CMPL/article/view/CMPL0707110283A/29416, acesso em Dez 2020.

PACK, S. D. La invasión pacífica: Los turistas y la España de Franco. Madrid: Turne Noema, 2009.

PAGÉS, A. Cenar con Diotima: Filosofía y feminidad. Herder Editorial, 2018. 
PARDO BAZÁN, E. De mi tierra. A Coruña: Tipografía de la Casa de la Misericordia, 1888.

PORTELA SILVA, E.La colonización cisterciense en Galicia (1142-1250). Santiago. USC, 1981.

RIVOLTA, M. C., MONTENEGRO, M., MENEZES FERREIRA, L.; NASTRI, J. "Arqueología, multivocalidad y activación patrimonial en Sudamérica. No somos ventrílocuos", en Rivolta, M. C., Montenegro, M., Menezes Ferreira, L. y Nastri, J. (eds.): Arqueología, multivocalidad y activación patrimonial en Sudamérica: Buenos Aires: Fundación de Historia Natural Félix de Azara. Facultad de Ciencias Sociales. Universidad Nacional de la Pcia. de Buenos Aires, 2014, p.15-29.

RODRÍGUEZ CASTILLO, H. Os mosteiros dúplices en Galicia na Alta Idade Media. Un traballo sobre modelos sociais. Serie Trivium, 16. Noia: Toxosoutos, 2005.

RODRÍGUEZ FER, C. "Hölderlin y el vuelo de Valente". Ínsula 751-752, julio-agosto, 2009, p. 36-40.

SPIVAK, G. C. "Can the subaltern speak?", en Nelson, C. and Grossberg, L. (eds.): Marxism and the Interpretation of Culture: Urbana, IL: University of Illinois Press, 1988, p. 271-313.

TARLOW, S. "The Archaeology of Emotion and Affect". Annual Review of Anthropology, 41(1), 169-185, 2012. Disponível em: https://doi.org/10.1146/annurev-anthro-092611145944, acesso em Dez 2020.

TILLEY, C. A Phenomenology of Landscape. Places, Paths and Monuments. Oxford: Berg, 1994.

VALENTE, J. Á.Obras completas I. Barcelona: Galaxia Gutenberg/Círculo de Lectores, 2006.

VALENTE, J. Á. "Los dibujos de Tàpies. La escritura y el cuerpo". ABC de las Artes, 6 de marzo de 1998.

VILLARES, R. "Castles vs. Castros. The Middle Ages in the Construction of Galician National Identity", en D'Emilio, J. (ed.): Culture and Society in Medieval Galicia: A Cultural Crossroads at the Edge of Europe: 917- 946. Leiden: Koninklijke Bril NV, 2015.

WITMORE, C. L. "Archaeology and modernity, or archaeology and a modernist amnesia?" Norwegian Archaeology Review, 39(1): 2006, p. 49-52.

WOUTERS, M. "El Proyecto Historga: historia oral de Galicia". Historia y Fuente Oral, 3: 1990, p.179-183. 